\title{
Interpersonal Skills: An Analysis According to the Perspective of al-Quran and al-Sunnah
}

\section{Kemahiran Interpersonal: Satu Analisis Menurut Perspektif al-Quran dan al-Sunnah}

\author{
Nik Yusri Musa ${ }^{1 *}$, Marwan Ismail ${ }^{1}$, Muhammad Hafizuddin ${ }^{1}$ \\ ${ }^{1}$ Universiti Malaysia Kelantan, MALAYSIA \\ *Corresponding Author
}

DOI: https://doi.org/10.30880/jstard.2021.02.03.025

Received 30 September 2020; Accepted 30 November 2020; Available online 31 December 2020

\begin{abstract}
This article is a study on the concept of individual skills (Interpersonal skills) according to the perspective of the Qur'an and Sunnah. Writing and research related to individual skills according to Islamic perspective are hard to find, most of the writing-related to it is from Western scholars and of course according to their perspective. Such a situation occurs in most fields of knowledge that are professional, it does not happen in the field or discipline of knowledge that is core. Accordingly, it is not something that is difficult to interpret because this field of Interpersonal skills has been developed and processed as a professional field by Western scholars. The situation is in line with the development of secular Western civilization based on the separation of knowledge from religion and morality from life. This writing is based on qualitative methodology through observational and research approach which is later through the method of formulation of the nusus al-Quran and alSunnah. The texts will be analyzed to formulate key themes related to the concept of individual skills.
\end{abstract}

Keywords: Interpersonal skills, Islamic perspective, professional field, western scholars

\begin{abstract}
Abstrak: Kajian ini adalah mengenai kemahiran interpersonal di kalangan pemimpin NGO-BMI di Malaysia. Kebanyakan kajian mengenai kemahiran perorangan dilakukan oleh para pengkaji dari perspektif Barat. Manakala kajian berhubung kemahiran interpersonal berdasarkan perspektif al-Quran dan al-Sunnah kurang diberikan tumpuan. Khususnya, kajian yang melibatkan kepimpinan di NGO-BMI Malaysia. Justeru, kajian ini disusun bagi memenuhi dua (2) objektif utama iaitu ; (1) Meneroka konsep utama kemahiran perorangan berdasarkan perspektif sarjana Barat dan Islam dan 2) Menyenaraikan ciri-ciri kemahiran interpersonal Barat dan Islam menjadi amalan pemimpin NGO-BMI Malaysia. Kajian ini telah memilih pendekatan kualitatif deskriptif melalui analisis dokumen tulisan para sarjana bagi merumuskan tema-tema penting berkaitan dengan konsep kemahiran perorangan dalam persepektif sarjana Barat dan Muslim. Selain itu, teks temubual separa struktur yang telah ditranskrip bersama tujuh (7) pemimpin dari enam (6) NGO-BMI turut dianalisis bagi mencapai objektif kajian yang kedua. Hasil kajian mendapati terdapat tiga (3) tema utama mengenai kemahiran perorangan berasaskan al-Quran dan alSunnah. Hasil kajian juga mendapati majoriti kepimpinan NGO-BMI telah mengamalkan pendekatan kemahiran interpersonal secara hybrid iaitu kombinasi antara pendekatan Barat dan Islam.
\end{abstract}

Kata Kunci: Kemahiran interpersonal, kemahiran sosial, kemahiran komunikasi, organisasi bukan kerajaan (NGO) berkebajikan Melayu Islam, kepimpinan syura 


\section{Pengenalan}

Manusia yang sifatnya madani bi al-tab'i merupakan makhluk yang diberi anugerah al-Bayan oleh Allah s.w.t.. Kalimah al-Bayan dengan segala perincian dan pecahannya bermaksud penjelasan, huraian, memberi maksud atau kefahaman tentang sesuatu perkara. (al-Mu'jam al-Asasi, 179). Menurut Ibn Kathir, al-Tabari dan ahli tafsir yang lain sewaktu mentafsirkan firman Allah s.w.t. dalam surah al-Rahman, ayat 3-4

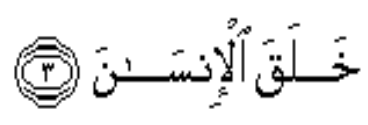

'Dia lah yang telah menciptakan manusia'

'Dia lah yang telah membolehkan manusia (bertutur) memberi dan menerima kenyataan'

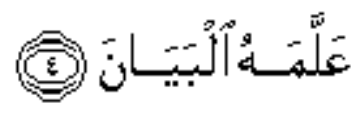

Manusia difitrahkan kejadiannya dengan keupayaan menghuraikan sesuatu yang terkandung dalam hati sanubarinya. Ia berupaya meluahkan keinginan, menterjemahkan maksud dan mafhum sesuatu perkara, membuat interpretasi, memberi nama, serta berinteraksi dan berkomunikasi antara sesama mereka. Keupayaam tersebut merupakan ni'mat anugerah Allah s.w.t. kepada manusia.

Manusia yang sifatnya madani bi al-tab'i iaitu manusia saling memerlukan sesama mereka berinteraksi, berkomunikasi dan beraktiviti dalam usaha meneruskan kehidupan, membina tamadun dan menggerakkan peradaban. Keupayaan berinteraksi dan berkomunikasi dengan baik dan berkesan sehingga menarik tumpuan dan perhatian orang lain adalah berbeza antara manusia. Sehubungan itu, rasulullah s.a.w. bersabda:

$$
\text { إن من البيان لسحرًا }
$$

Maksudnya: Sesungguhnya sebahagian dari pertuturan (huraian dan penjelasan) seumpama sihir (kerana dapat menarik perhatian dan tumpuan). Hadis riwayat Bukhari, dari Ibn 'Umar.

Nabi Musa a.s. memohon kepada Allah s.w.t. agar dijadikan Nabi Harun a.s. sebagai temannya untuk berdakwah atau berdailog dengan Firaun. Ini kerana nabi Harun a.s. lebih fasih dan jelas ungkapan bahasa dan percakapannya dibandingkan dengan beliau sendiri. Kisah ini diabadikan Allah s.w.t. dalam surah, al-Qasas, 34

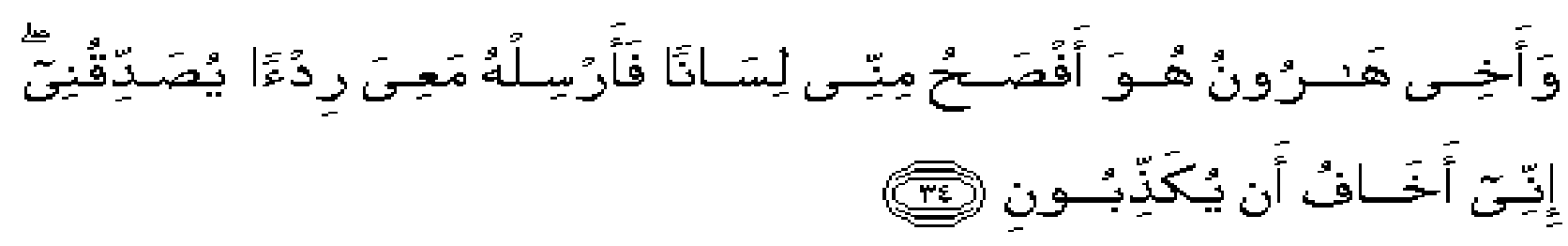

Maksudnya: Dan saudaraku - Harun, ia lebih fasih lidahnya daripadaku, maka utuslah dia bersama-samaku sebagai penyokong yang mengakui kebenaranku; sesungguhnya aku bimbang bahawa mereka akan mendustakan daku.

Al-Qasas 28:34|

Ayat dan hadis di atas menjelaskan beberapa perkara:

1. Perlunya kefasihan lidah dan kejelasan huraian dalam perkara-perkara yang berkaitan dengan dailog antara dua pihak.

2. Kefasihan lisan dan kelancaran ucapan merupakan anugerah Allah s.w.t. dan ia berlaku samada menerusi anugerah peribadi atau melalui proses pendidikan atau latihan.

3. Kefasihan lidah dan laras bahasa yang digunakan dapat menarik perhatian pendengar dan audien.

Penerokaan tanpa jemu terhadap nusus al-Quran dan al-Hadith, dengan memberi fokus kepada bidang-bidang kajian akan menemukan pembaca dan pengkaji dengan bidang pengetahuan dan disiplin ilmu yang dikaji. Nusus tersebut samada menyentuh secara langsung mahupun tidak langsung dengan bidang yang dikaji. Dalam aspek kemahiran perorangan umpamanya, dari aspek konsep, prinsip mahupun praktikal berdasarkan kepada suasana dan konteks yang diperlukan. Oleh yang demikian kajian ini bertujuan untuk memberi sumbangan kepada perkembangan epistemologi keilmuan Islam berkaitan kemahiran interpersonal berasaskan kepada pedoman dan suluhan wahyu. 


\section{Konsep Kemahiran Perorangan Interpersonal Skills Menurut al-Quran dan al-Sunnah Definisi Interpersonal Skill}

Dikemukakan beberapa definisi daripada sarjana Barat sebagai panduan kepada penulisan seterusnya. Komunikasi interpersonal merupakan komunikasi yang berlaku diantara komunikator dengan komunikan. Komunikasi ini efektif dalam mengubah sikap, pendapat atau perilaku seseorang.

Menurut Horward Gardner (1983) mendefinisikan kemahiran interpersonal sebagai kebolehan memahami orang lain dan menggunakan kebolehan ini dalam berinteraksi, bekerjasama, membimbing dan menguruskan komunikasi. Kemahiran ini membolehkan seseorang memahami perasaan, tabiat dan hasrat orang lain. kemahiran ini dapat membantu dalam berkomunikasi dan berkerjasama dengan orang lain dalam menghasilkan suatu projek yang berfaedah dan dapat memberi motivasi kepada orang lain.

Cangara (2010) komunikasi interpersonal merupakan proses komunikasi yang berlangsung antara dua orang atau lebih secara berhadapan. Manakala menurut Enjang (2009) komunikasi interpersonal ialah komunikasi antara beberapa orang secara bersemuka, yang memungkinkan setiap perserta menangkap reaksi yang lain secara langsung baik komunikasi secara verbal ataupun tidak verbal (nonverbal).

Selain daripada itu Kellerman dan Peter (2001) mendefinisikan komunikasi interpersonal sebagai komunikasi yang memiliki karekteristik yang itu komunikasi yang terjadi daripada satu orang ke satu orang yang lain, komunikasi berlangsung secara bersemuka dan hasil daripada komunikasi yang berlaku membawa kepada tindak balas atau kesan terhadap individu itu ketika komunikasi berlaku.

Kesimpulannya, komunikasi interpersonal merupakan satu komunikasi yang berlaku secara bersemuka, sama ada untuk bertukar idea, memberi pandangan atau sebagainya yang berlaku secara verbal muhupun bukan verbal (nonverbal). Melalui komunikasi ini, komunikator dapat menangkap terus reaksi yang dikeluarkan oleh komunitan. Daripada definisi yang dikemukakan itu secara umumnya dapat dirumuskan menurut perspektif Islam.

\section{Kemahiran Interpersonal Skill Para Anbiya}

Para anbiya pada setiap zaman dan tempat mewakili masyarakat mereka, mengetuai kaum dan sebagai pemimpin serta pembimbing bagi umat dan bangsa mereka. Firman Allah s.w.t.:

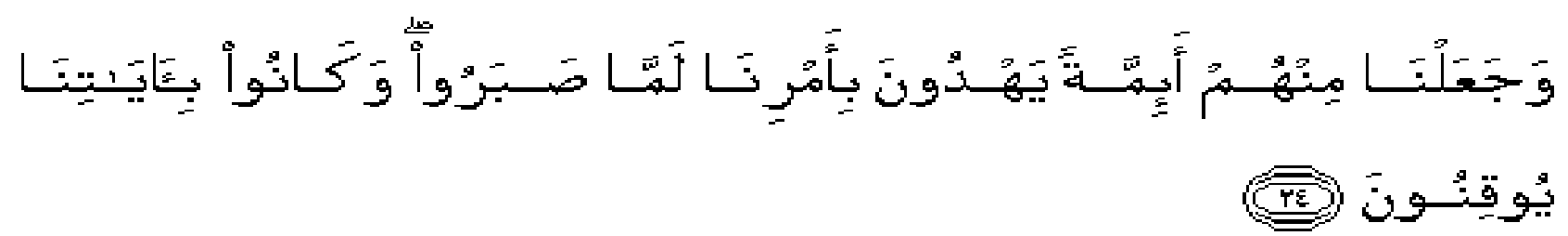

Dan Kami jadikan dari kalangan mereka beberapa pemimpin, yang membimbing kaum masing-masing kepada hukum agama Kami, selama mereka bersikap sabar (dalam menjalankan tugas itu) serta mereka tetap yakin akan ayat-ayat keterangan Kami.

As-Sajdah 32:24

Firman Allah s.w.t.:

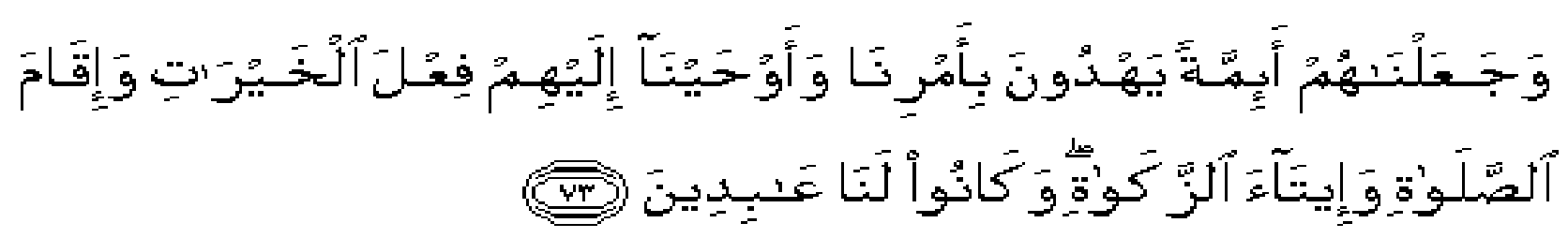

Dan Kami jadikan mereka ketua-ketua ikutan, yang memimpin (manusia ke jalan yang benar) dengan perintah Kami, dan Kami wahyukan kepada mereka mengerjakan kebaikan, dan mendirikan sembahyang, serta memberi zakat; dan mereka pula sentiasa beribadat kepada Kami.

Al-Anbiyaa' 21:73|

Sabda Rasulullah s.a.w. menjelaskan peranan para nabi dalam kalangan bani Israil.

$$
\text { حديث أبي هريرة ح قال: قال رسول الله } \square \text { :كانت بنو إسر ائيل تسوسهم الأنبياء، كلما هلك نبي خلفه نبي، }
$$

Maksudnya: Bani Israil dipimpin oleh para anbiya sepanjang zaman dahulunya, setiap kali wafatnya nabi maka ia diganti oleh nabi yang lain.

Pendekatan, kaedah dan ciri-ciri kepimpinan para anbiya sebagai panduan kepada umat untuk memahami konsep kepimpinan dan kemahiran interpersonal menurut suluhan wahyu 


\section{Kepimpinan}

\section{A. Tenang dan Berkeyakinan Sewaktu Menghadapi Krisis}

Kisah nabi Musa a.s. dan pengikutnya yang dikejar oleh Firuan bersama tenteranya dengan segala kekuatan dan persiapan diabadikan Allah s.w.t. dalam al-Quran. Berlaku situasi keadaan yang cukup getir apabila Musa a.s. dan pengikutnya di halang oleh laut didepannya, manakala firaun dengan tenteranya mengejar dari belakang. Ayat dibawah membuktikan ketenangan dan keyakinan nabi Musa sebagai pemimpin kepada pengikut-pengikutnya. Disaat pengikutpengikut panik, bimbang dan ketakutan, maka nabi Musa a.s. sebagai pemimpin menunjukan sikap tenang dan berkeyakinan dengan pertolongan Allah s.w.t.

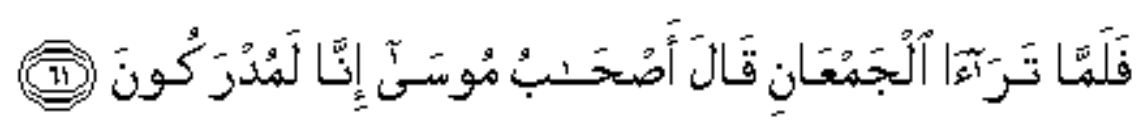

Setelah kedua-dua kumpulan itu nampak satu sama lain, berkatalah orang-orang Nabi Musa: "Sesungguhnya kita akan dapat ditawan".

Asy-Syu'araa' 26:61

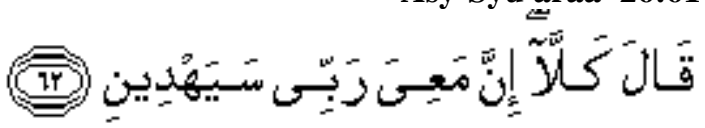

Nabi Musa menjawab: "Tidak! Jangan fikir (akan berlaku yang demikian)! Sesungguhnya aku sentiasa disertai oleh Tuhanku (dengan pemuliharaan dan pertolonganNya), Ia akan menunjuk jalan kepadaku".

Asy-Syu'araa' 26:62

\section{B. Memahami Isu dan Masalah Yang Berkaitan Sehingga Dapat Menyelesaikannya Dengan Baik Dan Diterima Bersama}

Isu yang berlaku difahami secara mendalam sebelum memberikan hukuman atau menetapkan sesuatu ketetapan. Ia sebagaimana digambarkan Allah s.w.t. kepada nabi Sulaiman a.s. yang menjatuhkan hukuman berbeza dengan hukuman yang telah lakukan oleh nabi Daud a.s. Hikmah dan ilmu telah dikurniakan Allah s.w.t. kepada kedua-duanya a.s. namun kefahaman kepada isu yang berlaku hanya diberikan anugerah kepada nabi Sulaiman. Hukuman yang dijatuhkan oleh nabi Daud a.s. adalah tepat dan tiada silapnya, namun hukuman daripada nabi Sulaiman a.s. adalah lebih tepat berdasarkan isu dan masalah yang berlaku.

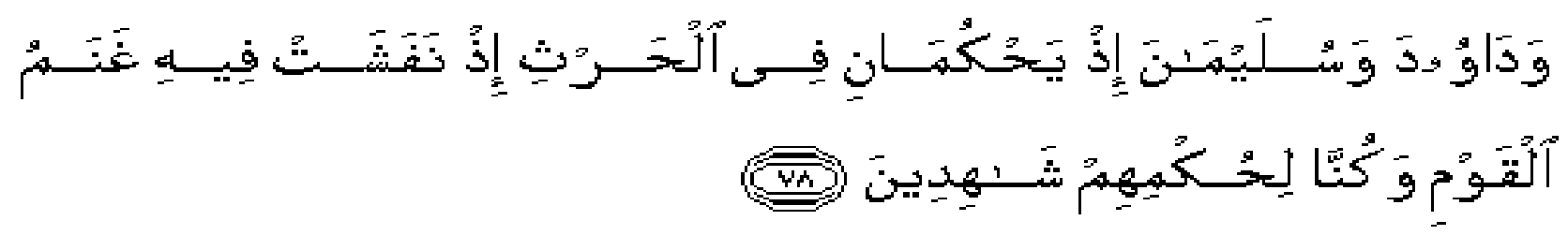

Dan (sebutkanlah peristiwa) Nabi Daud dengan Nabi Sulaiman, ketika mereka berdua menghukum mengenai tanamantanaman semasa ia dirosakkan oleh kambing kaumnya pada waktu malam; dan sememangnya Kamilah yang memerhati dan mengesahkan hukuman mereka.

Al-Anbiyaa' 21:78|

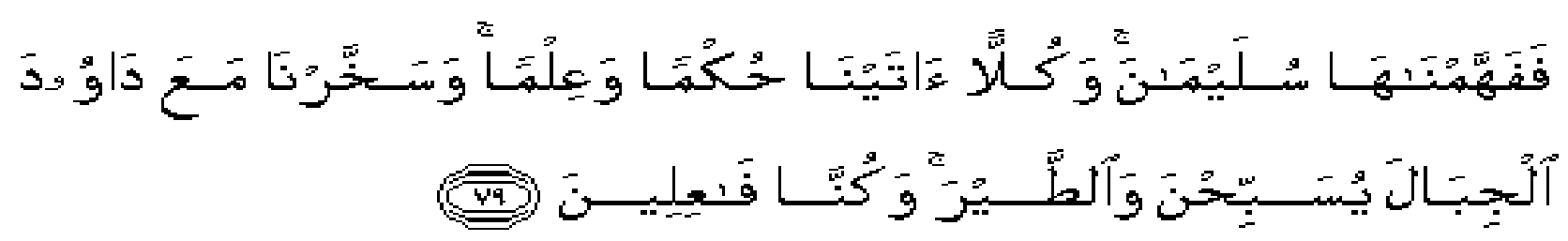

Maka Kami beri Nabi Sulaiman memahami hukum yang lebih tepat bagi masalah itu; dan masing-masing (dari mereka berdua) Kami berikan hikmat kebijaksanaan dan ilmu (yang banyak); dan Kami mudahkan gunung-ganang dan unggas memuji Kami bersama-sama dengan Nabi Daud; dan adalah Kami berkuasa melakukan semuanya itu.

Al-Anbiyaa' 21:79

Ayat berkaitan peristiwa penghakiman nabi Daud a.s. dengan anakandanya nabi Sulaiman a.s. sebagainamana di nyatakan di atas bermaksud bahawa, kefahaman nabi Sulaiman a.s. terhadap isu yang berlaku dan ketetapan hukuman yang diambil merupakan anugerah Allah s.w.t. kepadanya. Walaupun hikmat dan kebijaksanaan juga dianugerahkan kepada bapanya nabi Daud, namun kefahaman terhadap isu dan ketepatan hukuman hanya dianugerahkan kepada nabi Sulaiman. 
Dalam tamadun keilmuan Islam, merupakan sebahagian dari sumber ilmu dan dilihat dari aspek tersebut maka selain dari wahyu yang dianugerahkan kepada para anbiya, mereka juga dianugerahkan dengan ilham dan kaifiat atau mekanismanya berbeza-beza antara para nabi dengan nabi yang lain.

\section{Sabar dan Tegas dengan Karenah dan Gelagat Pengikut}

Para anbiya diakui oleh Allah s.w.t. sebagai insan yang teguh lagi mantap kesabarannya, terutamanya para $u l u$ al'azm dalam kalangan para anbiya. Namun dalam kesabaran yang teguh itu, mereka tetap tegas dengan keputusan yang dibuat, bersikap pemutus kepada hukuman yang telah dijatuhkan.

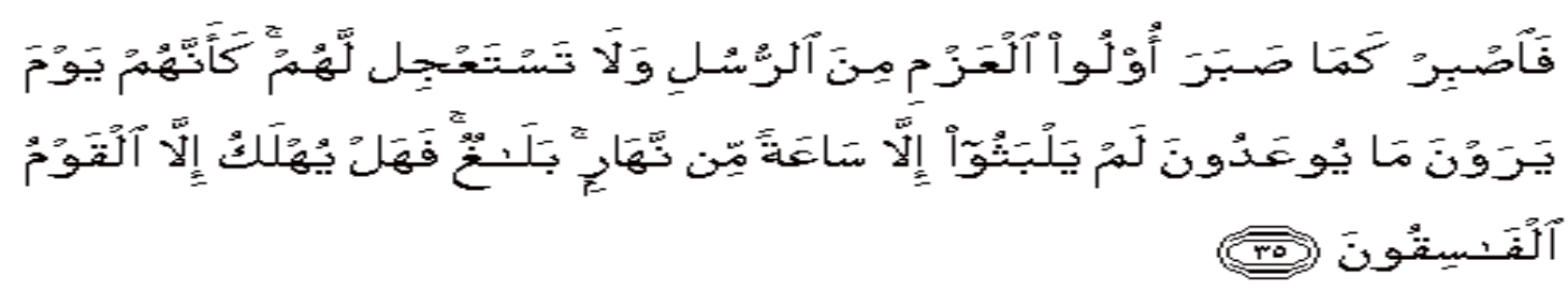

(Jika demikian akibat orang-orang kafir yang menentangmu wahai Muhammad) maka bersabarlah engkau sebagaimana sabarnya Rasul-rasul "Ulil-Azmi" (yang mempunyai keazaman dan ketabahan hati) dari kalangan Rasul-rasul (yang terdahulu daripadamu); dan janganlah engkau meminta disegerakan azab untuk mereka (yang menentangmu itu). Sesungguhnya keadaan mereka semasa melihat azab yang dijanjikan kepada mereka, merasai seolah-olah mereka tidak tinggal (di dunia) melainkan sekadar satu saat sahaja dari siang hari. (Penerangan yang demikian) cukuplah menjadi pelajaran (bagi orang-orang yang mahu insaf). Maka (ingatlah) tidak dibinasakan melainkan kaum yang fasik - derhaka.

Al-Ahqaaf 46:35

\section{Hubungan yang Teguh dengan Allah S.W.T}

Para anbiya a.s. selain daripada mempunyai hubungan yang erat dan sealiran dengan manusia mereka juga a.s. mempunyai hubungan yang padu lagi mantap dengan Allah s.w.t.. Manusia dilayan sebagaimana sepatutnya menurut kedudukan mereka, justeru Allah s.w.t. mengkritik rasulullah s.a.w. apabila baginda tidak melayan Abdullah bin Umi Maktum yang rabun matanya sebagaimana seharusnya ia dilayan. Walaupun tujuan atau matlamat daripada layanan baginda rasul yang menyinggung perasaan sahabatnya Abdulah bin Umi Maktum itu adalah baik iaitu mengharapkan keislaman pembesar kaum Qurais yang sedang berbicara dengan baginda, namun Islam menegaskan bahawa matlamat tidak menghalalkan cara. Kisah ini dapat dilihat menerusi permulaan surah 'abasa, $80: 1-9$

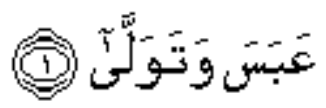

'Ia memasamkan muka dan berpaling'

'Kerana ia didatangi orang buta'
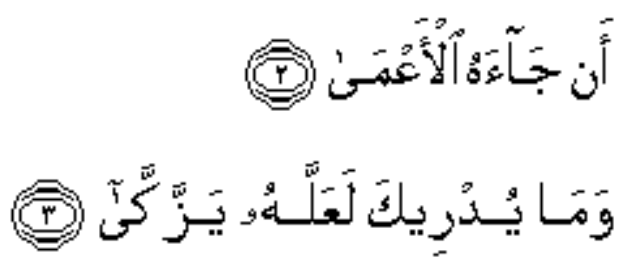

'Dan apa jalannya engkau dapat mengetahui (tujuannya, wahai Muhammad) ? Barangkali ia mahu membersihkan hatinya (dengan pelajaran agama yang didapatinya daripadamu)! -‘

Janganlah melakukan lagi yang sedemikian itu! Sebenarnya ayat-ayat Al-Quran adalah pengajaran dan peringatan (yang mencukupi).

Dalam permasalahan hubungan dengan Allah s.w.t. maka dapat dilihat melalui hadis rasulullah s.a.w.:

$$
\text { فعن حذيفة بن اليمان رضى الله عنه قال : كان النبي صلى الله عليه وسلم: إذا حزبه أمر صلى }
$$

Maksudnya: Adalah rasulullah s.a.w. apabila dibebani atau dirisaukan dengan sesuatu perkara maka baginda segera melakukan solat 


\section{Komunikasi Menurut Suluhan Wahyu}

Berdasarkan kepada nusus al-Quran dan al-Sunnah, maka dapat dirumuskan beberapa bentuk komunikasi. Antaranya ialah:

\section{A. Mengucapkan Ucapan atau Perkataan yang Baik (وقولوا للناس حسنا) )}

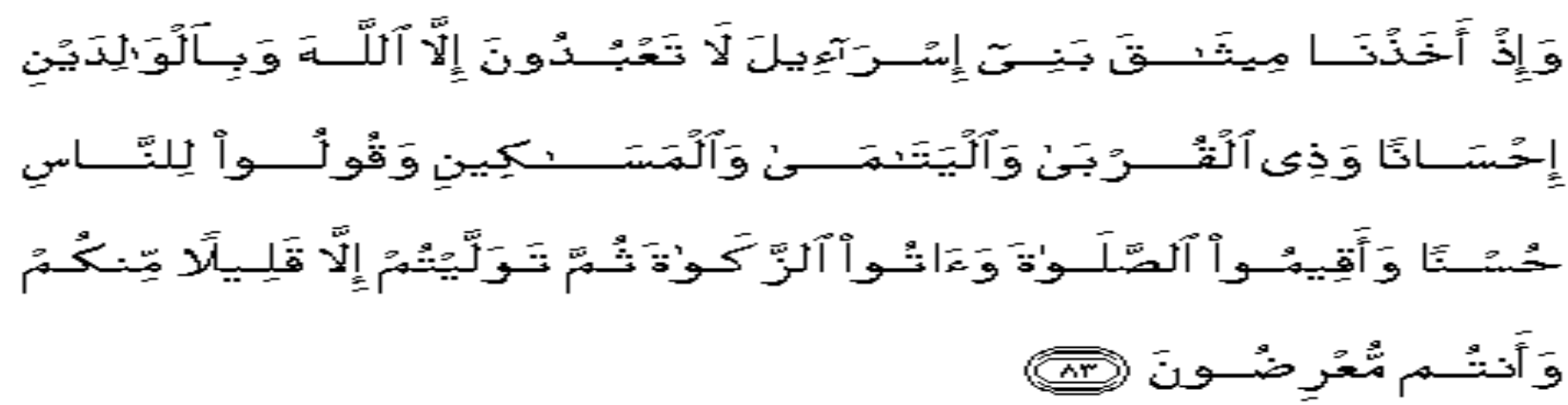

Dan (ingatlah wahai Muhammad), ketika Kami mengikat perjanjian setia dengan Bani Israil (dengan berfirman): "Janganlah kamu menyembah melainkan Allah, dan berbuat baiklah kepada kedua ibu bapa, dan kaum kerabat, dan anak-anak yatim, serta orang-orang miskin; dan katakanlah kepada sesama manusia perkataan-perkataan yang baik; dan dirikanlah sembahyang serta berilah zakat". Kemudian kamu berpaling membelakangkan (perjanjian setia kamu itu) kecuali sebahagian kecil dari kamu; dan sememangnya kamu orang-orang yang tidak menghiraukan perjanjian setianya. (al-Baqarah, 2:83)

Maksud ucapan atau perkataan yang baik ialah sebagaimana dinyatakan oleh baginda rasul melalui hadis-hadisnya.

$$
\text { الجنة لا يأمن جاره أنس بن مالك قال قال رسول الله صلى الله عليه وسلم لا يستقيم إيمان عبد حتى يستقيم قلبه ولا يستقيم قلبه حتى يستقيم لسانه ولا يدخل رجل }
$$

Maksudnya: Tidak akan murni iman seseorang sehingga tulus hatinya, tidak akan tulus hatinya sehingga benar lidahnya, tidak akan masuk syurga seseorang yang mana jirannya tidak aman dari kebejatan lidahnya.

Dalam hadis yang lain baginda s.a.w. menegur Aisyah r.a. apabila isterinya menjawab salam Yahudi dengan jawapan yang kasar lagi menyakitkan.

عن عائشة رضي اله عنها أن اليهود أنوا النبي صلى الله عليه وسلم فقالوا السام عليك قال و عليكم فقالت عائشة السام عليكم ولعنكم الله و غضب عالِ عليكم فقال

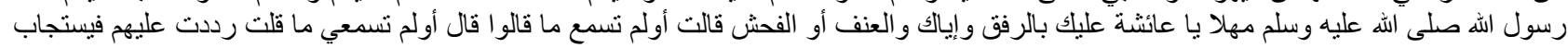
لي فيهم و لا يستجاب للهم في اله علي

Maksudnya: Sesungguhnya sekumpulan Yahudi mendatangi rasulullah s.a.w., lantas mengucapkan, kematianlah ke atas engkau, lalu di jawab oleh baginda, ke atas kalian juga begitu, lantas Aisyah menjawab, ke atas kalian kematian dan laknat Allah dan kemurkaanNya, maka rasulullah s.a.w. menegur Aisyah dengan bersabda ' apa ini Aisyah? Bersikaplah dengan lemah lembut dan usah sekali engkau keras lagi kasar dengan sumpah seranah, lalu Aisyah bertanya, Apakah rasul tidak mendengar apa yang dikatakan kepada engkau, Rasulullah menjawab, apakah engkau tidak mendengar jawapan ku kepada mereka? Aku telah menjawab ke atas mereka, Allah mustajabkan permintaan ku dan tidak sekali-kali dimustajabkan ucapan mereka kepada ku.

\section{b. Mengucapkan Ucapan yang Betul Lagi Benar (Al-Qawl Al-Sadid)}

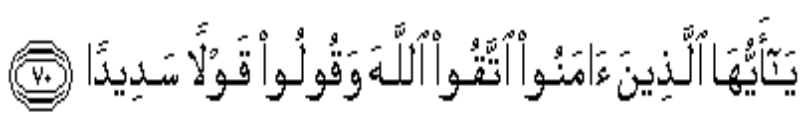

Wahai orang-orang yang beriman, bertaqwalah kepada Allah, dan katakanlah perkataan yang tepat - benar (dalam segala perkara). (al-Ahzab, 33:70)

Antara tafsiran dan maksud al-Qawl al-Sadid ialah ucapan atau perkataan benar, betul yang menimbulkan kegembiraan dalam hati orang yang sedang dilayani serta melahirkan semangat kebaikan dan persaudaraan serta menghilangkan permusuhan dalam kalangan manusia. 
Setiap ucapan, ungkapan dan perkataan yang membawa kepada ketenangan, ketenteraman serta penerimaan yang baik dari orang yang dihadap bercakap serta menimbulkan perasaan penerimaan dalam kalangan masyarakat dikira sebagai al-qawl al-Sadid.

Tidak dapat dinafikan bahawa kata-kata yang dituturkan memberi kesan yang mendalam samada kepada kawan atau lawan semasa berkomunikasi. Berapa banyak permusuhan dapat diselesaikan hanya kerana sepatah ucapan, dapat diperhatikan juga bagaimana kebencian yang membuak-buak dapat ditenteramkan kerana ucapan kata-kata yang meruntun jiwa. Namun, sejarah peradaban manusia juga membuktikan bahawa berapa banyak permusuhan adalah lantaran ucapan kata-kata yang dihamburkan. Benarlah sabda junjungan Rasul,

$$
\text { وهل يَكُبُّ الناس في النار على وجو ههم إلا حصائد ألسنتهم }
$$

Maksudnya: dan tiadalah yang menjerumuskan manusia ke dalam neraka melainkan lantaran angkara lidah mereka.

\section{c. Mengucapkan Ucapan yang Lembut (Al-Qawl Al-Layyin )}

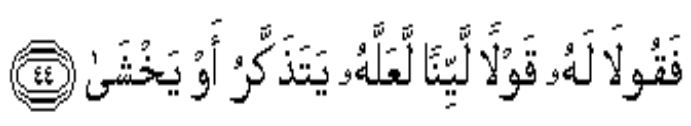

Kemudian hendaklah kamu berkata kepadanya, dengan kata-kata yang lemah-lembut, semoga ia beringat atau takut.

(Taha, 20:44)

Maksud al-Qawl al-Layyin ialah ucapan atau perkataan lemah lembut yang menyentap hati seseorang agar kembali kepada dirinya sendiri, bermuhasabah dengan kekurangan diri dan kembali kepada fitrah kejadiannya. Ini berdasarkan kepada firman Allah s.w.t. berkaitan dengan seruan nabi Musa kepada Firaun:

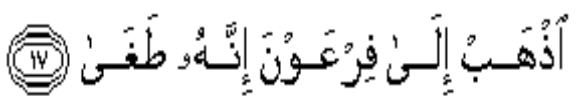

(Lalu diperintahkan kepadanya): Pergilah kepada Firaun, sesungguhnya ia telah melampaui batas (dalam kekufuran dan kezalimannya)

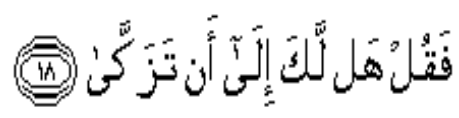

Serta katakanlah kepadanya: `Adakah engkau suka hendak mensucikan dirimu (dari kekufuran)

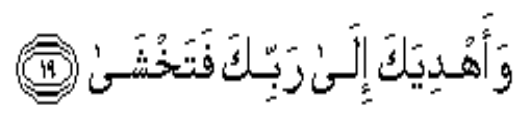

Dan mahukah, aku tunjuk kepadamu jalan mengenal Tuhanmu, supaya engkau merasa takut (melanggar perintahNya)

\section{Kesimpulan}

Melihat kepada pedoman al-Quran dan al-Sunnah berkaitan kemahiran interpersonal, kaedah komunikasi dan interaksi maka dapat dirumuskan bahawa bidang ini berkaitan secara langsung dengan muamalah interaksi manusia dalam kalangan mereka berasaskan kemahiran individu dalam menghuraikan maksud keinginan berteraskan akhlak dan keindahan budi pekerti. Ia dikategorikan dalam konsep habl min al-nas dan juga makarim al-khuluq. Kenyataankenyataan al-Quran dan al-Sunnah tersebut sekalipun berkaitan dengan konsep dakwah manusia kepada Islam, namun secara konsepnya, ia sebagai asas pemikiran dalam bidang kemahiran interpersonal, komunikasi dan interaksi sesama manusia. Setiap individu lebih memahami dirinya sendiri, dengan siapa ia berkomunikasi dan berinteraksi, mengenai bidang apa ia berbicara serta bagaimana seharusnya ia berbincang maka ia bergantung kepada idea, inovatif serta kreativiti mereka sendiri. Setiap individu tentunya mahir dan memahami bidang tugas serta disiplin bidang yang diceburi, justeru ia perlu amanah dan jujur dengan dirinya sendiri, benar dan ikhlas kepada Allah s.w.t. sebagai Tuhannya, serta mempunyai sifat perihatin serta empty dengan siapa yang berbicara.

Konsep-konsep asas ini sebenarnya sebagai teras hubungan sesama manusia yang membawa kepada kesejahteraan dan ketenteraman hidup. Habl min al-Nas ialah berinteraksi, berkomunikasi dan berurusan dengan manusia atas asas akhlak yang baik dan dapat diterima secara bersama tanpa mengira perbezaan bangsa dan anutan agama. 


\section{Penghargaan}

Penulis ingin mengucapkan terima kasih kepada Universiti Malaysia Kelantan atas bantuan dan maklumat yang diberikan untuk memastikan kejayaan kajian ini.

\section{Rujukan}

[1] Pimpinan al-Rahman, Al-Quran dan Terjemahannya, JAKIM. 1983

[2] Munazamah al-'Arabiyyah li al-Tarbiyyah wa al-Thaqafah wa al-'Ulum, al-Mu'jam al-Asasi, 1989, Laros

[3] Aamir Khan dan Wisal Ahmad. 2012. Leader's Interpersonal Skills and Effectiveness at Difference Level of Management. International Journal of Business and Social Science. Vol 3. No. 4 (Special Issue-Febuary 2012)

[4] Azhar. 2017. Komunikasi Antarperibadi Suatu Kajian Dalam Perspektif Komunikasi Islam. Jurnal al-Hikmah Vol. IX, No 14 Jan s/d Juni 2017

[5] Bambacas, M dan Patrikson, M. (2008). Interpersonal Communication Skills that Enhance Organisational Commitment. Journal of Communcation Management vol. 12. No 1.2008 pp 51-72

[6] Barakat. NG. 2007 . Interpersonal Skills. Libyan Journal of Medicine. 2(3) September 2007. www.ljm.org.ly

[7] H.M Nasor. 2015. Komunikasi Interpersonal Orang Tua Muslim dalam Pembinaan Akhlak Remaja : Studi di Kelurahan Way Huwi jati Agung, Lampung Selatan. Ijtamaiyya, Vol.8. No.1, Febuari 2015

[8] Li-Na Zhang, 2018. Importance of Interpersonal Skills at Work towards Managing People in an Educational Context. Advances in Economics, Business and Management Research (AEBMR), volume 54

[9] Zulkifli Arifin \& Sharifah Hayati Syed Ismail . 2016. Komunikasi Interpersonal dalam Pengurusan Organisasi Menurut Islam : Satu Analisis di Kumpulan Jaminan Perniagaan Telekom Malaysia Berhad. Global Media Journal - Malaysian Edition Volume 6, Issue 1, 2016 